\title{
THE RELATIONSHIP BETWEEN THE AVAILABILITY OF LACTATION FACILITIES, MOTHERS' KNOWLEDGE, AND EXCLUSIVE BREASTFEEDING AMONG FEMALE FACTORY WORKERS IN SIDOARJO DISTRICT
}

\author{
Billah Rizqa ${ }^{1}$, Chatarina Umbul $\mathbf{W}^{1}$ \\ ${ }^{1}$ Departement of Epidemiology \\ Faculty of Public Health, Airlangga University, Surabaya , Indonesia \\ Correspondence Address: Billah Rizqa \\ E-mail: billahrizqa20@gmail.com
}

\begin{abstract}
According to UNICEF, in 2013 there were 136,700,000 live births, but only about $32.6 \%$ of these babies received breast milk exclusively. In developing countries, only about $39 \%$ of mothers breastfeed exclusively. Indonesia has targetted for $80 \%$ exclusive breastfeeding. However, it has not been achieved. A large number of women in the workforce and the unavailability of breastfeeding facilities are among the factors influencing the low coverage of exclusive breastfeeding in Indonesia. In addition, maternal knowledge is also a contributing factor for exclusive breastfeeding practices This study aims to analyze the relationship between the availability of lactation facilities and maternal knowledge with exclusive breastfeeding. The execution of this research was conducted quantitatively with the descriptive research type. The design of this study is case-control. The study's population were female factory workers who had babies in Sidoarjo District. The sample size is 42 case samples and 42 control samples. The research sample was taken using a simple random sampling technique. The data was retrieved through survey methods with questionnaires. The results of the study show that there is no relationship between knowledge and exclusive breastfeeding $(\mathrm{p}=0.200)$ and there is a relationship between the availability of lactation facilities and exclusive breastfeeding $(\mathrm{p}=0.049)$. Mothers who work in factories with lactation facilities have a 2.667 times greater opportunity to give exclusive breastfeeding to their babies than mothers without access to lactation facilities $(\mathrm{OR}=2.667)$. The researchers suggest factories to provide lactation facilities and visitation activities by the local health office.
\end{abstract}

Keywords: Exclusive breastfeeding, Lactation facilities, Mother's knowledge

\section{INTRODUCTION}

The Sustainable Development Goals (SDG's) indicator stated that by 2030 the health and welfare of Indonesian citizens of all ages must be guaranteed. According to the WHO (2005) as referred by the Ministry of Health of the Republic of Indonesia (2014), to reduce high mortality and child morbidity rates, UNICEF and the WHO suggest parents to exclusively give breastmilk to infants aged 0-6 months, without the intake of drinks or other foods. Furthermore, additional food other than breastmilk should be given to children older than 6 months and breast milk should still be given until the child reaches 24 months. Exclusive breastfeeding means providing breast milk for infants in addition to other drinks such as mineral water (except medicine, mineral drops, or vitamins) and without other foods. Based on UNICEF's data (2013) as stated by Agustina (2018), out of 136,700,000 live births only about $32.6 \%$ of babies received exclusive breastfeeding. Meanwhile, around 39\% of mothers in developing countries provided exclusive breastfeeding to their babies.

Indonesia is targeting for $80 \%$ exclusive breastfeeding. However, according to the Indonesian Demographic and Health Survey (IDHS) 2012 data, the achievement of exclusive breastfeeding was only $42 \%$. According to Provincial Health Office (Provincial health office) in 2013, the achievement of exclusive 
breastfeeding was around $54.3 \%$. This has not met the established target set by the government (Ministry of Health of the Republic of Indonesia, 2014). The large number of the female workforce and lack of lactation facilities in the workplace are indicators that affects the low achievement of exclusive breastfeeding in Indonesia.

A survey conducted by the Central Stastics Body in Indonesia in 2013 showed an increase in the number of the female labor force in Indonesia. The number of workers in Indonesia is 114 million and $43.3(38 \%)$ million are women. A total of 25 million of these female workers are productive age workers (Ministry of Health of the Republic of Indonesia, 2015). To maintain the performance of female workers, companies must provide adequate facilities needed by the female workers.

Law No. 13/2003, articles 82 and 83 explain that women workers have the right to rest for 18 months after giving birth and 18 months before giving birth. The calculation of the birth must be based on the calculation of the obstetrician or midwife. Moreover, female workers who have children who still need breast milk should be given facilities to breastfeed or milk their children.

Knowledge about exclusive breastfeeding for children is a basic factor that must be possessed by a mother. Good knowledge related to the importance of giving exclusive breastfeeding to her baby will shape the mothers' behavior to exclusively breastfeed their babies (Agustina, 2016). Apart from knowledge, supporting factors are also needed, and a form of support from the workplace are lactation facilities. According to the Ministry of Health Regulation Number 15 of 2013, the lactation room is defined as a room intended for counseling related to breastfeeding, storing milk, breastfeeding, milking, and storing breast milk.

Based on these problems, the researchers analyzed the correlation between the availability of lactation facilities and mothers' knowledge of exclusive breastfeeding for factory workers in Sidoarjo District.

\section{METHOD}

This study was quantitative research as it involved a testing process that uses statistical tests to analyze the relationship of each variable. The research method used was the descriptive method. The data collection technique was casecontrol which compares the case group and the control group. The study was conducted in the Sidoarjo District. The mothers who work in factories were randomly drawn from 24 villages. The study was conducted from April 2019 to June 2019.

The population in this study were all women factory workers who had babies in the Sidoarjo district. The sample calculation was taken from the proportion of similar studies with an OR of 3.5. The case study sample was mothers who work in factories who do not provide exclusive breastfeeding, while the control sample are mothers who work in factories who provide exclusive breastfeeding. The inclusion criteria used were mothers who work in factories who were still actively working and had babies that were at least 6 months old in the Sidoarjo district area. The size of the study's subjects was calculated using the formula of case-control study proportions with 42 control samples and 42 case samples. Lottery and simple random sampling methods were used as sampling techniques. Four respondents were drawn from each village.Mothers' knowledge on the importance of giving exclusive breastfeeding to infants was evaluated through a questionnaire sheet consisting of 6 questions. The measurement results are categorized intohigh for the range of $50 \%$ to $100 \%$ and low for the range of $0 \%$ to $50 \%$.

The availability of lactation facilities is defined as a facility that must be provided by the factory to support the government's program to promote the exclusive collection of breast milk for up to 
6 months. This allows the mother to still be able to breastfeed even while working. Lactation facilities can be described as a room that has been equipped with facilities for breastfeeding such as a bottle for the breast milk, a pumping device, and storage for the breast milk in a coolbox. These facilities are the independent variables of the study. Exclusive breastfeeding by giving babies only breast milk for the first full 6 months acts as the dependent variable of the study.

Data was collected by using a selfdeveloped questionnaire with a validity test of 0.455 which can be filled by selecting the answers provided by the researcher. Each question has a score which is then added up. The Chi-square test statistic can determine if there is a relationship between the variables. This is used to analyze the data that has been obtained so that we can see the results of the correlation between variables. The research ethics certificate was issued with certificate number 201/HRECC.FODM/V/ 2019 by the Faculty of Dental Medicine, Universitas Airlangga.

\section{RESULTS}

\section{General Description of the Sidoarjo District}

The Sidoarjo district is $62.56 \mathrm{~km}^{2}$ and consists of 95,885 male residents and 98,166 female residents, with a total of 194,051 inhabitants. There are 24 villages in the Sidoarjo subdistrict, including Banjarbendo, Blurukidul, Bulusidokare, Celep, Cemengbakalan, Cemenkalang, Urangagung, Suko, Lemahputro, Teak, Sumput, Sarirogo, Pucanganom, Lebo, Sidokumpul, Sekardangan, Magersari, Gebang, Rangkahkidul, Suko, Lemahputro, Teak, Sumput, Sarirogo, Pucanganom, Lebo, Sidokumpul, Sekardangan, Magersari, Gebang, Rangkahkidul, Sidangkap Pucang, Sidokare, and Pekauman. This research was conducted in all of the villages and sub-districts mentioned above.

\section{Description of Exclusive Breastfeeding}

Exclusive breastfeeding means providing breast milk for infants in addition to other drinks such as mineral water (except medicine, mineral drops, or vitamins) and without other foods. The frequency distribution of breastfeeding by mothers who work in factories is as follows.

Table 1. Rate of exclusive breastfeeding among factory workers in the Sidoarjo district

\begin{tabular}{lcc}
\hline \multirow{2}{*}{ Breastfeed } & \multicolumn{2}{c}{ Total } \\
\cline { 2 - 3 } \multicolumn{1}{c}{ (c) } & n & \% \\
\hline$>6$ months & 42 & 50.0 \\
\hline$<6$ months & 42 & 50.0 \\
\hline Total & 84 & 100 \\
\hline
\end{tabular}

Based on Table 1, 42 (50.0\%) respondents breastfed their babies for more than 6 months and the rest $(50.0 \%)$ respondents breastfed less than 6 months to their babies.

\section{Overview of Mother's Knowledge Level}

Factory workers' knowledge is determined from how she understands the importance of giving exclusive breastfeeding to infants.

Table 2. Levels of knowledge of female factory workers in the Sidoarjo district

\begin{tabular}{lcc}
\hline \multirow{2}{*}{ Knowledge } & \multicolumn{2}{c}{ Total } \\
\cline { 2 - 3 } & n & \% \\
\hline High & 64 & 76.2 \\
\hline Low & 20 & 23.8 \\
\hline Total & 84 & 100 \\
\hline
\end{tabular}

Based on Table 2, 64 (76.2\%) respondents had high knowledge and 20 (23.8\%) respondents had low knowledge. Thus, the majority of mothers are highly knowledgeable about exclusive breastfeeding. 
Description of Lactation Facility
Availability

Lactation facilities could be placed in different strategic locations for accessibility by the female workers. The distribution of the availability of lactation facilities is shown below.

Table 3. Lactation facility at the factories in the Sidoarjo district

\begin{tabular}{lcc}
\hline \multirow{2}{*}{ Lactation Facility } & \multicolumn{2}{c}{ Total } \\
\cline { 2 - 3 } & $\mathbf{N}$ & $\boldsymbol{\%}$ \\
\hline Available & 46 & 54.7 \\
\hline Not available & 38 & 45.2 \\
\hline Total & 84 & 100 \\
\hline
\end{tabular}

Based on Table 3, 46 (54.7\%) respondents have lactation facilities at the factory and $38(45.2 \%)$ respondents did not have lactation facilities at the factory. Therefore, it can be concluded that most factories in the Sidoarjo district have provided lactation facilities for their workers.

\section{The Relationship between Mother's Knowledge Level and Exclusive Breastfeeding}

Below is the result of the correlation analysis on the level of knowledge of mothers who work in factories and exclusive breastfeeding.

Table 4. Relationship between mother's knowledge level and exclusive breastfeeding in the Sidoarjo district

\begin{tabular}{|c|c|c|c|c|}
\hline \multirow[t]{2}{*}{ Knowledge } & \multicolumn{2}{|c|}{$\begin{array}{c}\text { Breastfeed } \\
>6 \text { months }\end{array}$} & \multicolumn{2}{|c|}{$\begin{array}{l}\text { Breastfeed } \\
<6 \text { months }\end{array}$} \\
\hline & $\mathbf{N}$ & $\%$ & $\mathbf{n}$ & $\%$ \\
\hline High & 35 & 41.7 & 29 & 34.5 \\
\hline Low & 7 & 8.3 & 13 & 15.5 \\
\hline Total & 42 & 50 & 42 & 50 \\
\hline \multicolumn{5}{|c|}{$p$-value $=0.200$} \\
\hline \multicolumn{5}{|c|}{$\mathrm{OR}(\mathrm{CI} 95 \%)=-$} \\
\hline
\end{tabular}

Based on Table 4, 35 (41.7\%) respondents were highly knowledgeable and exclusively breastfeed. Thirteen $(15.5 \%)$ respondents had low knowledge and did not exclusively breastfeed. The statistical tests conducted produced a $\mathrm{P}$ value $=0.200$ where the $\mathrm{P}$-value $>\alpha$ indicate that there was no correlation between the level of knowledge and exclusive breastfeeding.

\section{Relationship between the Availability of Lactation Facilities and Exclusive Breastfeeding}

Below is the result of an analysis of the relationship between the availability of lactation facilities and exclusive breastfeeding.

Table 5. Relationship between the availability of lactation facilities and exclusive breastfeeding for factory workers in the Sidoarjo district

\begin{tabular}{|c|c|}
\hline \multirow[t]{2}{*}{$\begin{array}{l}\text { Lactation } \\
\text { Facilities }\end{array}$} & $\begin{array}{cc}\text { Breastfee } & \text { Breastfee } \\
\text { d }>6 & d<6 \\
\text { months } & \text { months }\end{array}$ \\
\hline & $\%$ \\
\hline Available & $\begin{array}{lll}28 & 33.3 & 18\end{array}$ \\
\hline Unavailable & $\begin{array}{lll}14 & 16.7 & 24 \\
\end{array}$ \\
\hline Total & 50 \\
\hline \multicolumn{2}{|c|}{$P$-Value $=0.049$} \\
\hline \multicolumn{2}{|c|}{ OR $($ CI 95\% $)=2.667$} \\
\hline \begin{tabular}{l}
\multicolumn{1}{c}{ Based } \\
respondents ga \\
and received 1 \\
factory. Me \\
respondents d \\
breastfeeding a \\
facilities from \\
tests produced \\
P-value is less \\
correlation be \\
lactation fa \\
breastfeeding \\
factories
\end{tabular} & $\begin{array}{l}\text { Table } 5,28 \text { (33.3\%) } \\
\text { exclusive breastfeeding } \\
\text { tion facilities from the } \\
\text { vhile } 24 \quad(28.6 \%) \\
\text { not provide exclusive } \\
\text { did not receive lactation } \\
\text { factory. The statistical } \\
\text { value }=0.049 \text { where the } \\
n \alpha \text {, meaning there is a } \\
\text { en the availability of } \\
\text { es and exclusive } \\
\text { mothers who work in }\end{array}$ \\
\hline
\end{tabular}


Furthermore, the statistical test results show that the odds ratio (OR) with a 95\% CI of 2.667 is between $1.099-6.468$, which means there is a significant risk. It can be concluded that the risk of not giving exclusive breastfeeding by mothers who work in factories with a lack of lactation facilities is 2.667 times greater than those of factory workers with the availability of lactation facilities.

\section{DISCUSSION}

According to Setyawati and Sutrisminah (2012), the inhibiting factors in exclusive breastfeeding include: 1) Limited time. The intensity of time spent together between working mothers and their babies is lower compared to stay-at-home mothers. 2) Distance between mother and baby. The most ideal condition for working mothers is to be able to breastfeed their babies whenever they want, with the mother and baby being together. 3) Mother's physical factors of fatigue. In general, mothers work eight to ten hours every day. Work fatigue is one of the complaints frequently conveyed by working mothers. When they arrive at home, the mother always demands to rest while the baby demands immediate breastfeeding. 4) Unavailability of nursing rooms or no storage facilities for breast milk. Only a few factories have breastfeeding/lactation rooms or breast storage facilities. Some companies do not provide adequate breastfeeding space or facilities for breastfeeding, even if it is just an empty room containing chairs, closed windows, and a sink. This prevents working mothers from breast pumping.

\section{The Relationship between Mother's Knowledge Level and Exclusive Breastfeeding}

Most of the factory workers mothers are very knowledgeable about exclusive breastfeeding. However, the results found that there is no correlation between the level of maternal knowledge and exclusive breastfeeding behavior.
These results support previous research which found that there was no correlation between maternal knowledge and exclusive breastfeeding behavior in infants (Pitaloka, et al., 2018). Yuliarti (2008) also found similar results as she found that there was no correlation between maternal knowledge and exclusive breastfeeding.

$$
\text { Conversely, Handayani, }
$$

Yunengsih, and Solikhah (2014) found that there was a correlation between the level of mothers' knowledge and exclusive breastfeeding. Mothers with low knowledge are 1.784 times more likely to not exclusively breastfeed than mothers with high knowledge. Septiani, Budi, and Karbito (2017) also found a correlation between knowledge and exclusive breastfeeding with an odds ratio value of 10.3 , meaning that a well-informed mother will be 10.3 times more likely to exclusively breastfeed than a quite knowledgeable mother. Moreover, Nurdiana (2015) also found that there is a correlation between the level of maternal knowledge and breastfeeding exclusively in the work area of the Bonorowo Primary Healthcare Center (Pusat Kesehatan Masyarakat). She found that the greater the mothers' willingness to breastfeed illustrates the mothers' high level of knowledge and vice versa.

Knowledge is one of the predisposing factors that can make it easier to shape a person's behavior. Breastfeeding behavior will be bad when the level of knowledge about breastfeeding is low (Notoatmodjo, 2007). The absence of a correlation between maternal knowledge and exclusive breastfeeding found in this study could be due to external factors that the researcher cannot control. For example, the habit of local residents to provide complementary foods (crushed rice or bananas) so that babies feel full so that babies do not cry at night and can fall asleep. In addition, differences in the characteristics of respondents can also affect the results of the analysis. 


\section{Relationship between the availability of lactation facilities and exclusive breastfeeding}

The results of this study indicate that the majority of mothers who work in factories receive lactation facilities from their workplaces and there is a correlation between the availability of lactation facilities with exclusive breastfeeding. These results support the research by Septiani, Budi, and Karbito (2017) who found that there is a significant correlation between exclusive breastfeeding with the availability of lactation facilities. The analysis showed that mothers who were provided lactation facilities were 6.9 times more likely to breastfeed exclusively compared to mothers who were not provided with these facilities. These results also support Nurdiana's (2015) research that found a significant correlation between the availability of lactation facilities and exclusive breastfeeding. In sum, the more complete the facilities provided, the higher the exclusive breastfeeding. In addition, this study supports Sutrisno's (2015) research findings which explained that there was an influence on the availability of lactation space by exclusive breastfeeding. The RR value $>1$ is 4.138 which means that the availability of breastfeeding space will have a 4 times greater effect on exclusive breastfeeding behavior.

However, the findings of the present study does not support Paramita's (2016) findings which stated that there was no correlation between the lactation facility and exclusive breastfeeding behavior. This is because almost all of the study's respondents' workplaces do not provide a lactation facility.

The knowledge of mothers who work in factories related to exclusive breastfeeding and the attitude of mothers who work in factories related to exclusive breastfeeding while working is one of the predisposing factors. Supporting factors are needed to improve the behavior of working mothers to provide exclusive breastfeeding. Providing a good physical environment for breastfeeding is a form of supporting factor. A good physical environment is when a company provides lactation facilities that are equipped with breastfeeding facilities, breastfeeding counseling, and a place to express milk and store the results. The triggering factors can be in the form of behavior and attitudes of health care providers in motivating and educating mothers who work in factories, specifically related to breastfeeding.

\section{CONCLUSION}

The study concludes that the majority of women factory workers are highly knowledgeable about exclusive breastfeeding and most receive lactation facilities in their workplaces. The results of the analysis show that there is no correlation between the knowledge of mothers with exclusive breastfeeding behavior and there is a correlation between the availability of lactation facilities and exclusively breastfeeding for mothers who work in factories.

In improving exclusive breastfeeding, mothers who are also factory workers are suggested to continue giving breast milk even when they are working. Pumping and storage in cool boxes can be done. The local health department is expected to help monitor factory workers to encourage them to continue to provide exclusive breastfeeding for a full 6 months as they are supported by lactation facilities provided by the factory. The local health department should also follow up on factories that have not provided lactation facilities. In addition, counseling to factory owners regarding the importance of exclusive breastfeeding must also be held so that mothers are sure that they can do this with the support of their workplace.

\section{REFERENCES}

Agustina (2018) Hubungan Pemberian ASI Eksklusif dengan Kejadian Stunting pada Balita Usia 24-59 Bulan di 
Puskesmas Kraton Yogyakarta. Universitas 'Aisyiyah Yogyakarta.

Agustina, T. A. (2016) 'Hubungan antara Pengetahuan dengan Pemberian ASI Eksklusif di Desa Dukuhwaru Wilayah Kerja Puskesmas Dukuhwaru Kabupaten Tegal Tahun 2015', Electronic Journal Politeknik Harapan Bersama Tegal, 5(1), pp. 123-125. doi: http://dx.doi.org/10.30591/siklus.v 5i1.303.g295.

Handayani, L., Yunengsih and Solikhah (2014) 'Hubungan Pengetahuan dan Teknik Menyusui dengan Pemberian ASI Eksklusif di Wilayah Kerja Puskesmas Pengasih II Kabupaten Kulonprogo', Jurnal Kesmasindo, 6(3), pp. 232-239.

Ministry of Health Republic of Indonesia (2014) 'Infodatin: Situasi dan Analisis Diabetes'. Jakarta: Data and information Center.

Ministry of Health Republic of Indonesia (2015) Dukung Ibu Bekerja Beri ASI Eksklusif.

Notoatmodjo, S. (2007) Promosi Kesehatan dan Ilmu Perilaku. Jakarta: Rineka Cipta.

Notoatmodjo, S. (2010) Promosi Kesehatan Teori dan Aplikasi. Jakarta: Rineka Cipta.

Nurdiana, I. (2015) Hubungan Tingkat Pengetahuan Ibu dan Ketersediaan Fasilitas Penunjang ASI Eksklusif dengan Pemberian ASI di Wilayah Kerja Puskesmas Bonorowo Kabupaten Kebumen. Universitas Muhammadiyah Surakarta.
Paramita, I. (2016) Hubungan antara Jenis Pekerjaan Ibu dengan Keberhasilan Pemberian ASI E 6 Bulan Pertama di Puskesmas Rangkah Surabaya. Universitas Airlangga.

Pitaloka, D. A., Abrory, R. and Pramita, A. D. (2018) 'Hubungan antara Pengetahuan dan Pendidikan Ibu dengan Pemberian ASI Eksklusif di Desa Kedungrejo Kecamatan Waru Kabupaten Sidoarjo', Amerta Nutr, 2(3), pp. 265-270. doi: 10.20473/amnt.v2.i3.2018.265270.

Septiani, H., Budi, A. and Karbito (2017) 'Faktor-Faktor yang Berhubungan dengan Pemberian ASI Eksklusif oleh Ibu Menyusui yang Bekerja Sebagai Tenaga Kesehatan', Aisyah: Jurnal Ilmu Kesehatan, 2(2), pp. 159-174. doi: https://doi.org/10.30604/jika.v2i2.6 2.

Setyawati, I. and Sutrisminah, E. (2012) 'Pentingnya Motivasi dan Persepsi Pimpinan Terhadap Perilaku Pemberian ASI Eksklusif pada Ibu Bekerja', Majalah Ilmiah Sultan Agung, 50(127), pp. 1-14.

Sutrisno, A. H. (2015) Ketersediaan Ruang Menyusui terhadap ASI Eksklusif pada Ibu Bekerja di Sleman. Sekolah Tinggi Ilmu Kesehatan 'Aisyiyah Yogyakarta.

Yuliarti, I. D. (2008) Hubungan Pengetahuan dan Sikap Ibu dengan Perilaku Pemberian ASI Eksklusif. Universitas Sebelas Maret Surakarta. 